\title{
POLA INTERAKSI EDUKATIF GURU-MURID TERHADAP \\ PENINGKATAN AKHLAKUL KARIMAH: ( Studi Multisitus di MIN Tolobali dan SDIT Insan Kamil Kota Bima)
}

\author{
Dewi Masitha \\ Fakultas Tarbiyah Institut Agama Islam Muhammadiyah Bima \\ Kampus: Jalan Anggrek No. 16, Ranggo Na'e \\ Email: Masithadewi.21@gmail.com
}

\begin{abstract}
Abstrak:
Penelitian ini dilakukan untuk mengetahui bagaimana pola interaksi gurumurid di MIN Tolobali dan SDIT Insan Kamil Kota Bima. Penelitian ini menggunakan pendekatan penelitian kualitatif, dengan rancangan penelitian studi multisitus. Informan terdiri dari yaitu kepala sekolah, waka kurikulum, waka kesiswaan, guru-guru serta guru akidah akhlak dan beberapa siswa. Metode pengumpulan data dilakukan dengan observasi, wawancara mendalam dandokumentsi. Analisis dilakukan dengan pengumpulan data, reduksi data, penyajian data, dan penarikan kesimpulan. Pemeriksaan keabsahan data dilakukan dengan trianggulasi. Hasil penelitian di SDIT Insan Kamil dan MIN Tolobali Kota Bima adalah dimana kedua sekolah tersebut menggunakan pola interaksi yang sama, yakni pola interaksi antara guru dan murid, guru dengan obejek belajar, serta murid dengan objek belajar akan tetapi peran guru di kedua sekolah tersebut berbeda. di SDIT Insan Kamil guru berperan sebagai monitor, fasilitator, pembimbing dan evaluator dalam interaksi guru dengan peserta didik sedangkan di MIN Tolobali Kota Bima guru berperan sebagai; pengajar, pendidik dan melatih dalam interaksi guru dengan peserta didik. Pola interaksi dari kedua sekolah tersebut sama-sama berpengaruh terhadap pembentukan akhlak peserta didik, akan tetapi dengan cara yang berbeda pula. SDIT Insan Kamil pembentukan karakternya melalui perencanaan nilai-nilai karakter di sekolah (interaksi edukatif di dalam kelas melalui proses pembelajaran) sedangkan di MIN Tolobali Kota Bima dalam pembentukan karakternya melalui program dan kegiatan pengembangan yang diterapkan di sekolah.
\end{abstract}

Kata Kunci: Interaksi Guru-Murid, Peningkatan Akhlakul Karimah

\section{PENDAHULUAN}

$\mathrm{M}$

anusia adalah makhluk individu dan makhluk sosial. Dalam hubungannya dengan manusia sebagai makhluk sosial, terkandung suatu maksud bahwa manusia bagaimanapun juga tidak dapat terlepas

dari individu yang lain. Secara kodrati manusia akan selalu hidup bersama. Hidup bersama antara manusia akan berlangsung dalam berbagai bentuk komunikasi dan situasi. Dalam hidup semacam inilah terjadi interaksi. Dengan demikian kegiatan hidup manusia akan selalu dibarengi dengan proses interaksi atau komunikasi, 
baik interaksi dengan alam lingkungan, interaksi dengan sesamanya, maupun interaksi dengan Tuhannya, baik itu disengaja maupun tidak disengaja. Dari berbagai bentuk interaksi, khususnya mengenai interaksi yang disengaja, ada istilah interaksi edukatif. Interaksi, edukatif ini adalah interaksi yang berlangsung dalam suatu ikatan untuk tujuan pendidikan dan pengajaran. Oleh karena itu interaksi edukatif perlu dibedakan dari bentuk interaksi yang lain. "Dalam arti yang lebih spesifik pada bidang pengajaran, dikenal adanya istilah interaksi belajar-mengajar. Dengan kata lain apa yang dinamakan interaksi edukatif, secara khusus adalah sebagai interaksi belajar-mengajar". (Sardiman, 2000: 1).

Interaksi belajar-mengajar mengandung suatu arti adanya kegiatan interaksi dari tenaga pengajar yang melaksanakan tugas mengajar di satu pihak, dengan warga belajar (siswa atau peserta didik/subjek belajar), yang sedang melaksanakan kegiatan belajar di pihak lain. Guru dan peserta didik memang dua figur manusia yang selalu hangat dibicarakan dan tidak akan pernah absen dari agenda pembicaraan masyarakat. Guru tidak hanya disanjung dengan keteladanannya, tetapi ia juga dicaci-maki dengan sinis hanya karena kealpaanya berbuat kebaikan, meski kesalahan itu bak setitik noda semata. Keburukan perilaku peserta didik cenderung diarahkan pada kegagalan guru membimbing dan membina peserta didiknya. Padahal warna perilaku peserta didik yang buruk, itu dapat terkonsumsi dari multi sumbera tau berbagai faktor.

Dalam konteks inilah, guru dan peserta didik haru memposisikan diri sebagai frase yang serasi, seimbang dan harmonis. Hubungan keduanya berada dalam relasi kewajiban yang saling membutuhkan. "Dalam perpisahan raga, jiwa mereka bersatu sebagai dwitunggal, guru mengajar dan peserta didik belajar dalam proses interaksi edukatif yang menyatukan langkah mereka kesatu tujuan yaitu kebaikan". Dengan demikian kemuliannya guru dapat meluruskan pribadi peserta didik yang dinamis agar tidak membelok dari kebaikan. (Syaiful Bahri Djamarah, 2000: 2). Sejalan dengan kondisi ideal tersebut, berdasarkan pra observasi penelitia di SDIT Insan Kamil dan di MIN Tolobali Kota Bima dalam membina, mendidik, membimbing dan memberikan motivasi kearah yang dicita-citakan, menujukan pola interaksi yang ingin diciptakan adalah hubungan guru dan peserta didik yang bersifat edukatif. Hubungan ineraksi yang dimaksud adalah dimana guru berinteraksi dengan pesera didik, peserta didik dengan peserta didik lainnya dan juga interaksi dengan sujek belajar yang mampu menciptakan suasanapembelajaran yang efektirf. Jadi interaksi edukatif disini adalah sebagai 
suatu proses hubungan timbal-balik anatara guru dan peserta didik yang mempenyai tujuan tertentu, yakni untuk mendewasakan peserta didik agar nantinya dapat berdiri sendiri, dapat menemukan jati dirinya secara utuh.

Proses interaksi edukatif di SDIT Insan Kamil dan di MIN Tolobali Kota Bima dilihat melalui bagaimana interaksi antara guru dan murid, bagaimana interaksi tersebut dapat membentuk akhlak peserta didik. Akhlak disini dapat diartikan sebagai sifat dan tingkah laku yang tumbuh dan menyatu di dalam diri seseorang atau siswa sebagai hasil atau dampak dari interaksi itu sendiri. Sifat yang tumbuh dari dalam jiwa itulah yang memancarkan sikap dan tingkah laku pebuatan seseorang. Oleh karena penanaman nilai di SDIT Insan Kamil dan di MIN Tolobali Kota Bima pada umumnya bertujuan hendak mendudukan manusia sebagai makhluk yang tinggi dan sempurna serta membedakanya dengan makhluk-makhluk lainya. Jadi tujuan pembelajaran adalah bagaimana bisa membelajarkan anak atau peserta didik melalu interaksi yang dilakukan di dalam ataupun di luar kelas, dengan cara penanaman nilai-nilai karakter mulia di setiap proses interaksi sehingga menjadikan manusia sebagai orang yang berkelakuan baik terhadap Tuhan, manusia dan lingkunganya. Berdasarkan latar belakang tersebut, maka penelitian ini memfokuskan mendeskripsikan "Pola Interaksi Edukatif Guru-Murid terhadap Peningkatan Akhlakul Karimah "(studi multisitus di MIN Tolobali Kota Bima dan SDIT Insan Kamil Kota Bima).

\section{TINJAUAN TEORITIS}

\section{Pengertian Interaksi Edukatif}

Manusia adalah makhluk ciptaan Allah SWT yang sifatnya sosial, dinamakan demikian karena dalam menjalankan aktifitas sehari-hari, manusia saling berinteraksi, tolong menolong serta saling membutuhkan antara yang satu dengan yang lainnya. Dalam menjalankan aktifitas sehari-hari antara yang satu dengan yang lainnya, akan berlangsung dalam berbagai bentuk komunikasi dan situasi, dari berbagai macam jenis situasi tersebut terdapat situasi khusus yaitu yang dinamakan situasi pembelajaran. Dalam situasi pembelajaran akan terjadi interaksi yang berlangsung dalam ikatan tujuan pembelajaran. Istilah interaksi, pada umumnya adalah suatu hubungan timbal balik (feed-back) antara individu yang satu dengan individu yang lainnya yang terjadi pada lingkungan masyarakat atau selain lingkungan masyarakat. Sehubungan dengan pengertian interaksi 
edukatif tersebut, dalam hal ini diperjelas oleh beberapa tokoh pendidikan antara lain:

a. Menurut Shuyadi dan Abu Achmadi pengertian interaksi edukatif adalah suatu gambaran hubungan aktif dua arah antara guru dan anak didik yang berlangsung dalam ikatan tujuan pendidikan.

b. Menurut Sadirman A.M pengertian interaksi edukatif dalam pengajaran adalah proses interaksi yang disengaja, sadar akan tujuan, yakni untuk mengantarkan anak didik ketingkat kedewasaannya.

c. Menurut Djamarah "Interaksi pendidikan (edukatif) ini terjadi dengan sadar yang didasari atas tujuan untuk mengubah tingkah laku dan perbuatan seseorang”. Dengan demikian, memunculkan istilah guru di satu pihak dan anak didik di lain pihak.Keduanya berada dalam interaksi pendidikan dengan posisi, tugas dan tanggung jawab yang berbeda, namun bersama-sama mencapai tujuan.

d. Guru dengan siswa mengadakan intaraksi yaitu dengan menggunakan berbagai gaya disebut dengan daya jiwa. Adapun daya-daya yang terpenting menurut Ngalim Purwanto "Adalah pengamatan, tanggapan, fantasi berpikir, peranan dan kemauan.” Ini berarti kecenderungan manusia untuk berhubungan dengan yang lain melahirkan komunikasi dua arah, baik melalui bahasa dan tindakan atau perbuatan. Karena ada aksi, maka reaksipun terjadi dan inilah unsur yang membentuk interaksi. Namun perlu dipahami bahwa interaksi sebagaimana dijelaskan di atas ini tidak sama dengan interaksi pendidikan. Oleh karenanya, interaksi di sekitar kehidupan manusia dapat diubah menjadi interaksi yang bernilai pendidikan.

e. Homansmendefisikan interaksi sebagai suatu kejadian ketika suatu aktivitas yang dilakukan oleh seseorang terhadap individu lain diberi ganjaran atau hukuman dengan menggunakan suatu tindakan oleh individu lain yang menjadi pasangannya. Konsep yang dikemukakan oleh Homans ini mengandung pengertian bahwa suatu tindakan yang dilakukan oleh seseorang dalam interaksi merupakan suatu stimulus bagi tindakan individu lain yang menjadi pasangannya.

f. Walgito, mengatakan interaksi sosial adalah hubungan timbal balik antara individu satu dengan individu lain. Individu satu dapat mempengaruhi individu yang lain atau sebaliknya, individu dengan kelompok, atau kelompok dengan kelompok. 
g. Menurut Soetomo "hubungan antara anak dan dengan orang tua dapat dikatakan mempunyai hubungan (interaksi) edukatif apabila salah satu pihak (orang tuanya) dalam hal itu mempunyai tujuan tertentu".

Dari beberapa pengertian tersebut, dapat ditarik sebuah kesimpulan bahwa pengertian interaksi edukatif guru dengan siswa adalah suatu proses hubungan timbal balik (feed-back) yang sifatnya komunikatif antara guru dengan siswa yang berlangsung dalam ikatan tujuan pendidikan, dan bersifat edukatif, dilakukan dengan sengaja, direncanakan serta memiliki tujuan tertentu. Dalam ilmu pendidikan, hubungan guru murid disebut juga interaksi edukatif.Dalam perspektif ilmu komunikasi, interaksi ini melibatkan guru sebagai komunikator dan murid sebagai komunikan.Hubungan kedua subjek ini biasanya mengintegrasikan sesuatu, yang dikenal dengan istilah pesan (message).Agar pesan itu sampai dengan efektif maka diperlukan media atau saluran (channel). Dengan demikian, ada empat unsur dalam hubungan atau komunikasi ini, yaitu komunikator, komunikan, pesan dan media. Dalam konteks hubungan guru murid, keempat unsur itu akan selalu ada. Proses belajar mengajar sebagai inti dari kegiatan belajar mengajar merupakan proses interaksi dua unsur manusiawi, yakni guru sebagai pihak yang mengajar dan siswa sebagai pihak yang belajar. Dalam situasi ini, siswa menjadi subjek pokoknya. Hal ini bermakna, bahwa interaksi yang sengaja di ciptakan berfokus pada kebutuhan dan kemampuan belajar siswa.

\section{Interaksi Belajar Mengajar Sebagai Interaksi Edukatif}

Pendidikan dan pengajaran berintikan interaksi antara pendidik dan peserta didik atau guru dengan murid.Interaksi ini biasanya menggunakan media bahasa yang disebut komunikasi.Agar dapat berkomunikasi dengan baik, guru perlu memiiki kemampuan berbahasa dengan baik, dan menguasai struktur kalimat dan ejaan yang benar.Juga harus pandai mengatur tinggi rendahnya suara dank eras lemahnya bicara. Juga tidak kalah penting dalam interaksi pendidikan dengan murid adalah penampilan, penampilan guru yang baik adalah yang moderat, memperlihatkan sikap bersahabat, keramahan, keterbukaan, penghargaan akan martabak siswa, kesedian untuk membantu dan lain-lain. Kemampuan komunikasi guru dalam kelas dipengaruhi oleh penguasaan bahan pengajaran dan penguasaan cara mengajar (metode yang digunakan). Adapun bentuk komunikasi yang dapat dilakukan oleh guru dalam rangka interaksi dengan murid antara lain: 1) Penyampian informasi lisan, 2) Penyampaian informasi tertulis, 3) Komunikasi melalui media elektronika, 4) Komunikasi dalam aktivitas kelompok. 
Selanjutnya dalam menyampaikan informasi kepada murid dikelas ataupun kelompok, hendaknya guru menyajikan informasi secara sistematis dan berurutan, berbicara terarah pada pencapaian tujuan, berbicara dengan semangat, tidak menunjukan kelesuhan atau kebosanan, penyampaian informasi diselingi dengan humor untuk menimbulkan rasa senang kepada murid, penyampaian informasi disertai dengan alat peraga, dan guru memberikan petunjuk dengan jelas dan lainlain. Proses belajar mengajar merupakan inti dari proses pendidikan secara keseluruhan, guru sebagai pendidik memegang peranan utama dalam proses belajar mengajar, yang terjalin dalam suatu kesatuan yang tidak dapat terpisahkan antara siswa yang belajar dan guru yang mengajar, karena diantara dua kegiatan ini terjalin suatu interaksi edukatif yang saling menunjang antara yang satu dengan yang lainnya. Proses belajar mengajar merupakan serangkaian perbuatan guru dan siswa atas dasar hubungan timbal balik (feed-back) yang berlangsung dalam situasi edukatif untuk mencapai tujuan tertentu, interaksi edukatif guru dengan siswa merupakan syarat utama bagi berlangsungnya proses belajar mengajar. Agar proses pendidikan merupakan interaksi antara guru dengan murid berjalan dengan baik dan mencapai tujuan yang ditetapkan, seorang guru harus memerlukan persiapan, baik dari segi penguasaan ilmu yang diajarkan, maupun kemampuan penyampaian ilmu, sehingga tepat sasaran kepada obyek didik yang bervariasi dan berkepribadian dan akhlaknya.

\section{METODE PENELITIAN}

Penelitian ini menggunakan jenis penelitian kualitatif, penelitian kualitatif merupakan jenis penelitian yang menekankan pada hasil pengamatan peneliti, dengan menggunakan desain penelitian tindakan. Disini peneliti bertindak sebagai observer aktif, yakni peneliti melakukan pengamatan terkait pola interaksi edukatif yang terjadi antara guru-murid dalam meningkatkan ahlakul karimah di SDIT Insan Kamil Kota Bima dan di MIN Tolobali Kota Bima. Selanjutnya, peneliti turut memberikan perlakuan terhadap pelaksanaan pembelajaran, melengkapi perancangan perangkat pembelajaran terkait metode dan strategi apa yang tepat untuk digunakan, melakukan interaksi dengan peserta didik serta mengikuti pelaksanaan kegiatan keagamaan di sekolah tersebut. Dalam hal ini peneliti juga bertindak sebagai evaluator peragkat pembelajaran guru serta memberikan syaran kepada kepala sekolah agar lebih mengawasi kinerja para guru dalam aktivitas interaksi edukatif di sekolah. 


\section{HASIL PENELITIAN DAN PEMBAHASAN}

\section{Pola Interaksi Edukatif Guru-Murid di SDIT insan Kamil}

Hasil penelitian mengenai pola interaksi edukatif dalam proses pembelajaran di SDIT Insan Kamil tahun ajaran 2014/2015 adalah sebagai berikut:

Guru sebagai monitor, fasiltator, pembimbing dan evaluator,

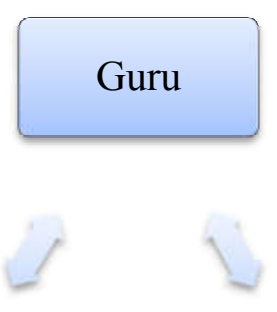

Guru sebagai Organisator

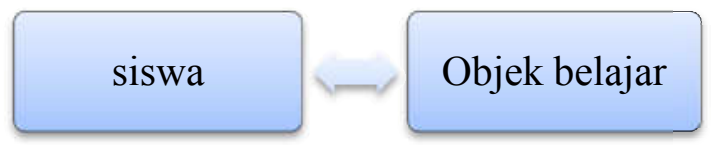

\section{Gambar: Bentuk atau Model Interaksi di SDIT Insan Kamil tahun ajaran 2014/2015}

Gambar di atas menunjukan hubungan aktif antara guru dengan siswa, guru dengan objek belajar, dan siswa dengan objek belajar. Interaksi antara guru dengan siswa terlihat saat guru berperan sebagai fasilitator, motinor, pembimbing dan evaluator kepada siswa saat proses pembelajaran berlangsung. Interaksi antara guru dengan objek belajar terlihat saat guru berperan sebagai organisator, yang mana guru sebelum pembelajaran berlangsung, guru membuat konsep pembelajaran, kemudian saat pembelajaran berlangsung. Guru menerapkan konsep pembelajaran tersebut dengan menggunakan media dan strategi pembelajaran yang berbeda, sehingga dalam menyajikan materi belajar dapat menarik perhatian dan mudah dipahami oleh peserta didik. Sedang guru sebagai pembimbing terlihat saat pembelajaran berlangsung, guru dalam pengajarannya tidak hanya mentrasferkan ilmu pengetahuan kepada anak didik namun bagaimana dalam pembelajaran itu guru mampu menanamkan nilai-nilai sosiol, yang sarat akan makna.

Interaksi antara siswa dengan objek belajar terlihat saat siswa mengerjakan tugas yang diberikan guru. Siswa juga merespon dan aktif terhadap materi pelajaran yang disampaikan oleh guru. Seperti yang dibahas sebelumnya bahwa proses pembelajaran disajikan dengan multi srtategi dan media pembelajaran hingga materi yg diajarkan terlihat menarik dan siswa akan lebih cepat tanggap 
atau memahaminya. Adapun penjelasan dari pola interaksi edukatif (dalam proses pembelajaran) terhadap peningkatan aklakul karimah di SDIT Insan Kamil adalah sebagai berikut:

\section{Interaksi guru dengan siswa}

Pola interaksi antara guru dengan siswa dalam proses pembelajaran di SDIT Insan Kamil guru mimiliki peran sebagai berikut:

1) Guru sebagai monitor

Guru bertindak memperhatikan dan memeriksa kegiatan yang dilakukan siswa selama pembelajaran, guru diharapkan mampu mengontrol perkembangan siswa dalam kelas selama melaksanakan kegiatan belajar baik secara individu, berpasangan maupun berkelompok. Peran guru di SDIT Insan Kamil sebagai monitor sangat bervariasi pada setiap guru. Seperti halnya ibu Astuti S.Pd, guru kelas 1B, inbu Nakmul Aswti, S.Sos.I guru kelas 1A, Nurmiati, S.Pd, guru kelas 3A mereka berperan sebagai monitor dalam proses pembelajaran di kelas dengan berbagai macam strategi dan media, misanya dalam menjelaskan materi jika ada siswa yang tidak mampu dalam memahami materi yang disampaikan, maka kewajiban guru menyampaikan materi dengan strategi yang lebih baik, memberian atau mengajukan pertanyaan yang berhungan dengan materi dan mendekati siswa yang kesulitan dalam belajarya.

2) Guru sebagai fasilitator

Aktivitas belajar di sini adalahaktivtas yang bersifat fisik maupun mental. Dalam pembelajaran, kedua aktivitas ini selalu terkait sebab keduanya mampu menghasilkan pembelajara yang optimal. Dalam aktivitas belajar yang perlu diperhatikan adalah menggunaan media pembelajaran, metode yang digunakan serta peran guru yang menyediakan kegala kebutuhan demi tersiptanya pembelajaran yang maksimal. Guru sebagai fasilitator memiliki peran memfasilitasi siswa-siswa untuk belajar secara maksimal dengan mempergunakan berbagai strategi, metode media, dan sumber belajar. Dalam proses pembelajaran siswa sebagai titik sentral, siswa yang lebih aktif, mencari dan memecahkan maslah belajar, dan guru membantu kesulitan siswa yang mendapat kendala, kesulitan dalam memahami dan memecahkan permasalahan. Guru sebagai fasilitator memunginkan kemudahan kegiatan belajar siswa, serta menciptakan lingkunagn belajar yang menyenangkan. 


\section{3) Guru sebagai pembimbing}

Proses pembelajaran akan terjadi manakala terdapat interaksi atau hubungan timbal balik antara siswa dengan lingkungannya dalam situasi edukatif unruk mencapai tujuan yang telah ditetapkan. Hubungan timbal balik ini merupakan syarat terjadinya proses pembelajaran yang didalamnya tidak hanya menitik beratkan pada tranfer of knowledge, akan tetapi juga tranfer of value. tranfer of knowledge dapat diperoleh siswa dari media-media belajar, seperti buku, majalah, tempat bersejarah (museum), guru dan sumber-sumber lain yang dapat menambah pengetahuan siswa. Akan tetapi tranfer of value hanya akan diperoleh siswa melalui guru yang menanamkan sikap dan nilai suatu materi dengan melibatkan aspek-aspek psikologis inilah yang tidak dapat digantikan oleh media manapun. Dengan demikian guru adalah media yang mutlak adanya dalam proses pembelajaran siswa.

4) Guru sebagai evaluator

Dalam dunia pendidikan, kita ketahuai bahwa setiap jenis pendidikan atau bentuk pendidikan pada waktu-waktu tertentu selalu diadakan evaluasi atau penilaian yang telah dicapai, baik oleh pihak terdidik atau pendidik. Demikian pula setiap kali proses belajar mengajar guru hendaknya menjadi evaluator yang baik. Penilaian dilakukan untuk mengetahui apakah tujuan yang dirumuskan itu tercapai atau tidak, apakah materi yang diajarkan sudah dikuasai atau belum oleh siswa, dan apakah metode atau strategi yang digunakan efisien atau tidak. Penilaia perlu dilakukan, kaena dalam penilaian seorang guru dapat mengetahui keberhasilan pencapaian tujuan, pengusaan siswa terhadap materi pelajaran, serta ketepata metode mengajar yang digunakan. Adapun tujuan lain dari penilaian adalah untuk mengetahuai kedudukan siswa di dalam kelas atau kelompoknya. Dalam penilaian, guru dapat menetapkan seorang siswa termasuk dalam kelompok siswa pandai, sedang, kurang, atau cukup baik di kelasnya, jikadi bandingkan dengan teman-temannya.

\section{Interaksi Guru Dengan Objek Belajar}

Pada pola interaksi antara guru dengan objek belajar dalam proses pembelajaran berlangsung. Guru juga berperan sebagai organisator dalam mengelola objek belajar dalam proes pembelajaran di kelas. Sebelum pembelajaran berlangsung para guru telah mempersiapka konsep pembelajaran, menyiapkan materi belajar, hal itu telah tertuang dalam perangkat pembelajaran yan biasa dinamakan RPP. Supaya pembelajaran lebih menarik dan siswa menjadi 
lebih aktif maka siswa menggunakan multi strategi dan media meskipun sederhana, tidak hanya proses pembeajaran di kelas yang perlu dipersiapan, tetapi juga suasana dan pengelolaan kelas perlu dikondisikan. Misalnya suasana kelas dihias agar terlihat lebih menarik supaya tercipta kondisi belajar yang nyaman dan efektif. Guru mengemas pelajaran dengan berbagai macam strategi dan metode, ada yang dibuat bagan atau catatan kecil yang dibat dikertas atau catatan kecil dikertas yang biasa dilakukan dikelas dan juga mengemas materi dengan gambar dan game. Hal ini dilakukan agar siswa lebih cepat dalam memahami materi yang diajarkan.

\section{Interaksi Siswa Dengan Objek Belajar}

Saat pola interaksi antara siswa dengan objek belajar dalam proses pembelajaran berlangsung. Ditandai pada saat siswa mengerjaka tugas yang diberikan guru. Objek belajar yang dikemas dengan media dan strategi yang tepat sehingga membuat siswa mampu memamahi jalannya proses pembelajaran, ditandai dengan siswa aktif dalam proses pembelajaran, siswa mampu berpikir kritis terkait objek belajar. Sehingga peran guru dalam proses interaksi edukatif antar siswa dengan objek belajar yaitu tercpiptanya ing ngarsa sung tuladha ( di depan memberi teladan), ing madya mangun karsa (di tengah guru memberikan dengan contoh, teladan, membangun kepribadian, karakter dalam pendidikan, dan lain sebagainya), tut wuri handayani ( di belakang guru memberi semangat dan dorongan kea rah yang lebih baik.) Maka dalam proses pembelajaran di SDIT Insan Kamil, dalam hal interaksi siswa dengan objek belajar guru mampu menjadi teladan bak sikap maupun pengetahuannya yang ditunjukan lewat kemampuan guru membuat konsep pembelajaran,membelajarakan anak didik, mampu merangkai contoh dan pengibaratan sesuai dengan tingkat berpikir dan pengalaman siswa, dan lain sebagainya. Dengan itu siswa lebih mudah memahami setiap materi belajar yang disampaikan. Sehingga dengan sendirinya mampu menjadi contoh bagi siswa dalam berinterksi dengan objek belajar.

Peran guru saat ditengah memberikan dengan contoh, teladan, membangun karakter, kepribadian dalam pendidikan, mencipta dan lain sebagainya kepada siswa saat berinteraksi degan objek beajar, seperti menggali kreativitas siswa dan mendampingi siswa daam memcahkan masalah belajarnya. Disini guru memberikan arahan kepada siswa, saat siswa memecahkan persoalan belajar sesuai dengan pemahaman mereka sendiri, disini guru tidak menuntut harus mengerjakan sesuai dengan keinginan guru, namun siswa dierkan kebebasan 
unutk mengembangkan pemikirannya terkait dengan objek belajar. Peran guru dalam memberikan semangat dan motivasi kepada siswa saat berinteraksi dengan objek belajar, seperti memberikan motivasi dan dorongan agar siswa memiliki semangat untuk belajar. Kemampuan dan jenjang berfikir siswa mengharuskan guru beradaptasi dengan itu dalam memberikan penguatan dan dorongan. Seperti memberian contoh keteladana dari kisah-kisah nabi dan para salafussaleh terkait perjuangan mendapatkan ilmudan kedudukan orang yang berilmu di dunia dan akhirat, mengemas pelajaran dengan baik dan kratif, dengan bermain dan bernyanyi. Jika motivasi belajar mampu ditumbuhkan dengan baik, maka siswa akan aktif dalam proses pembelajaran. Siswa juga akan mengerjakan apapun yang diperintahkan oleh guru. Maka hal pertama yang dilakukan oleh para guru di SDIT Insan Kamil dalam memulai aktivitas pemebejaran adalah dengan berdo'a terlebih dahulu sebelum belajar, elaborasi (motivasi dan kesiapan peserta didik dalam belajar) serta yel-yel penyemangat.

Pola interaksi antara siswa dengan objek belajar dengan baik jika keduanya aktif dan dibantu dengan peran guru, sarana dan prasarana yang memadai serta kesiapan guru mengikuti perkembangan teknologi sebagai penunjang aktivitas belajar. Peran guru tidak pernah lepas pada proses pembelajaran yang aktifuntuk dapat mencapai kopetensi belajar. Guru juga membantu siswa saat berinteraksi dengan objek belajar agar bisa dan mampu memenuhi kopetensi setiap materi yang disampaikan. Peran guru sangat penting dalam proses pembelajarn di kelas, hingga pola interaksi akan aktif dan tujuan kegiatan pembelajaran tercapai. Sebagai penghubung terjadinya pola interaksi edukatif yang demikian, maka kreativitas guru juga dituntut dalam membuat pembelajaran lebih menarik, guru juga menyiapkan strategi dan media pembelajaran yang sesuai dengan materi yang diajarkan. Yang nanti saat pembelajaran berlangsung akan terjadi interaksi yang aktif antara guru dengan siswa, guru dengan objek belajar serta interaksi siswa dengan objek belajar. Maka pola interaksi edukatif dalam proses pembelajaran di SDIT Insan Kamil menunjukan bahwa hubungan aktif antara guru denga siswa, guru dengan objek belajar, siswa dengan objek belajar. Interaksi antara guru dengan siswa terlihat saat guru berperan sebagai monitor, fasilitator, membimbing dan evaluator pada siswa saat proses pembelajaran berlangsung. Peran guru sebagai dengan objek beajar terlihat saat guru berperan sebagai organisator, yang mana guru sebelum pembelajaran berlangsung. Guru membuat dan menyediakan konsep 
pembelajaran. Interaksi siswa dengan objek belajar terlihat siswa aktif dalam pembelajaran, itu tercipta kerena guru merupakan sentral daam proses belajaran.

\section{Pola Interaksi Edukatif Guru-Murid di MIN Tolobali Kota}

Hasil penelitian mengenai pola interaksi edukatif dalam proses pembelajaran yang di MIN Tolobali Kota Bima tahun ajaran 2014/2015 adalah sebagai berikut:

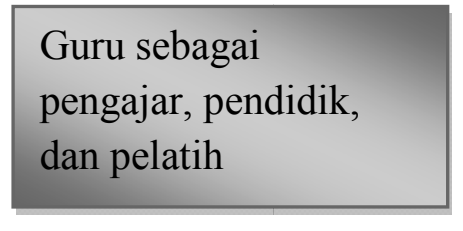

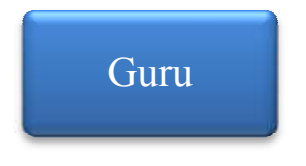

Guru sebagai monitor

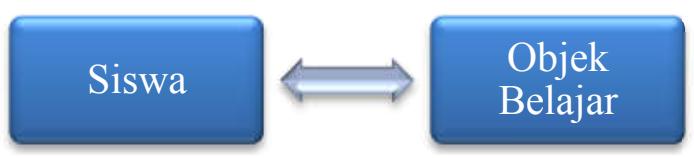

Gambar: Bentuk atau Model Interaksi Guru-Murid di MIN Tolobali Kota Bima.

Gambar tersebut menunjukkan hubungan aktif antara guru dengan siswa, siswa dengan objek belajar serta guru dengan objek belajar. Interaksi antara guru dengan siswa terlihat saat guru berperan sebagai pengajar, pendidik, dan pelatih. Interaksi guru dengan objek belajar terlihat pada saat proses pembelajaran, menyiapkan perangkat pembelajaran lengan dengan menggunakan media dan straegi pembelajaran yang bervariatif. Interaksi siswa dengan objek beajar terlihat saat guru memberikan tugas, dan siswa menanggapi apa yang disampaikan oleh gurunya. Adapun penjelasan dari pola interaksi edukatif dalam proses pembelajaran di MIN Tolobali Kota Bima adalah sebagai berikut:

\section{Interaksi Guru Dengan Siswa}

\section{1) Guru sebagai pengajar}

Peran guru sebagai pengajar, kadang diartikan hanya sebagai penyamoai pelajaran. Dalam posisi ini guru,guru aktif menempatkan dirinya sebagai pelaku impposisi yaitu mentranfer pengetahuan kepada siswa. Sedangkan dilain pihak, siswa secara pasif menerima materi pelajaran yang diberikan tersebut sehingga proses pembelajaran terkesan monoton. Padaha peran guru sebagai pengajar bukan hanya meyampaikan informasi, tetapi masih banyak kegiatan lain yang harus dilakukan guru agar proses pengajaran mencampai tujuan dengan efektif 
dan efisien. Hal ini sebagaimana yang dikomentari oleh ibu Kharunnisah, ST berikut:

"Mengajar bukan hanya sebatas menyampaikan ilmu pengetahuan yang dimiliki guru kepada siswa, sebab tugas guru itu sangat komplek dan berat dek, kami sebagai guru disini mengajar dengan kesadaran penuh yakni, sadar akan tugas kami dalam membelajarkan siswa, mengarahkan, membimbing dan menanamkan nilai. Mengajar hanya sebatas pemberian atau mentranferan ilmu jika yang mengajar itu hanya menganggap bahwa kehadirannya di sebuah madrasah itu hanya sebagai penggugur kewajiban ia sebagai seorang pengajar, karena yang demikian tidak ubahnya sama seperti seorang tamu yang kepergiannya tidak meninggalkan bekas sama sekali. Meskipun menjadi tamu dirumah orang lain, pasti ada kesan tersendiri bagi tuan rumah, apakah kesannya baik atau sebaliknya. Jadi jika guru berlaku hanya sebagai penggugur kewajibannya saja sebagai pengajar maka dalam diri siswa hanya terkesan yang tidak baik, oleh karena itu atau siapapunmengemban profesi sebagai guru harus berlandaskan keikhlasan, sehngga apapun yang menjadi tantangan dan cobaan bisa dihadapi dengan hati yang tenang. Jadi guru di MIN Tolobali ini tidak hanya sebagai guru yang mentranferkan ilmunya kepadapeserta didik".

Hal ini senada dengan hasil pengamatan peneliti bahwa;

"Pada saat guru mengajar memang sebagai medianya hanya papan tulis, guru menuliskan materi dipapan tulis pada materi penjumlahan di kelas 1, akan tetapi juga mengontrol kerja peserta didik. Membimbing anak yang belum mengerti cara penjumlahan, memotivasi siswa agar tetap berusaha mencoba meskipun anak sudah merasa tidak mampu. Ada kejadianketika pembelajaran berlangsung, ada anak yang menangis karena ternyata dia belum bisa menulis apalagi menghitung. Jadi peran guru disitu adalah menuntun siswa tersebut, setiap hari memberikan beberapa kalimat dengan menuliskan dengan ukuran agak besar di bukunya, sebagai bahan anak itu berlatih, guru juga menyampaikan masalah siswa tersebut kepada orang tuanya, agar dirumah dapat dilatih secara perlahan".

2) Guru sebagai pendidik

Guru sebagai seorang pendidik tidak hanya tahu tentang materi yang akan diajarkan. Akan tetapi, ia pun harus memiliki kepribadian yang kuat yang menjadikannya sebagai panutan bagi para siswanya. Hal ini penting karena sebagai seorang pendidik, guru tidak hanya mengajarkan siswanya untuk mengetahui beberapa hal. Guru juga harus melatih keterampilan, sikap dan mental anak didik. Penanaman keterampilan, sikap dan mental ini tidak bisa sekedar asal tahu saja, tetapi harus dikuasai dan dipraktikkan siswa dalam kehidupan sehariharinya. Mendidik adalah menanamkan nilai-nilai yang terkandung dalam setiap 
materi yang disampaikan kepada anak. Penanaman nilai-nilai ini akan lebih efektif apabila dibarengi dengan teladan yang baik dari gurunya yang akan dijadikan contoh bagi anak. Dengan demikian diharapkan siswa dapat menghayati nilai-nilai tersebut dan menjadikannya bagian dari kehidupan siswa itu sendiri. Jadi peran dan tugas guru bukan hanya menjejali anak dengan semua ilmu pengetahuan (transfer of knowledge) dan menjadikan siswa tahu segala hal. Akan tetapi guru juga harus dapat berperan sebagai pentransfer nilai-nilai (transfer of values).

3) Guru sebagai pelatih

Melatih dapat diartikan: (a) mengajar seseorang agar terbiasa (mampu) melakukan sesuatu; (b).membiasakan diri (belajar); (c) memahirkan. Melatih juga dapat diartikan sebagai pengekspresian sebuah bakat atau inspirasi yang ada baik secara teori maupun secara nalar/akal pikiran. Melatih adalah tehnik pembelajaran yang dilakukan dengan cara praktek langsung di lapangan sesuai dengan teori yang telah dijarkan oleh guru di kelas. Sesuai dengan tujuan yang ingin dicapai dalam materi pelajaran, melatih dibagi menjadi beberapa bagian yakni : (a) Melatih Fisik; (b) Melatih Mental; (c) Melatih Emosi; (d) Melatih keterampilan atau bakat

Guru harusberperan sebagai pelatih, yang bertugas untuk melatih peserta didik dalam pembentukan kompetensi dasar, sesuai dengan kompetensi masing-masing. Pelatihan yang dilakukan, di samping harus memperhatikan kompetensi dasar dan materi standar, juga harus mampu memperhatikan perbedaan individual peserta didik, dan lingkungannya. Untuk itu guru harus banyak tahu, meskipun tidak mencakup semua hal, dan tidah setiap hal secara sempurna, kerena hal itu tidaklah mungkin.

\section{Interaksi Guru Dengan Objek Belajar}

Pola ineraksi guru dengann objek belajar di MIN Tolobali adalah sebagai organisator dalam pembelajaran. Guru telah mempersiapkan bahan pembelajaran bahkan jauh-jauh hari, berupa konsep pembelajaran . menyiapkan materi, media dan strategi belajar. Penguasaan bahan oleh guru seyogyanya mengarah pada spesifikatas ilmu kecakapan yang diajarkanya. Mengingat isi, sifat, dan luasnya ilmu, maka guru harus mampu menguraikan ilmu atau kecakapan dan apa-apa yang akan di ajarkanya kedalam bidang ilmu atau kecakapan yang bersangkutan. Penyusunan unsur-unsur atau informasi-informasi yang baik itu bukan saja untuk mempermudah peserta didik untuk mempelajarinya, melainkan juga memberikan gambaran yang jelas sebagai petunjuk dalam menetapkan metode pengajaran. Menguasai bahan sebelum guru itu tampil di depan kelas untuk mengelola 
interaksi belajar mengajar, terlebih dahulu harus sudah menguasai bahan apa yang dikontakkan dan sekaligus bahan-bahan apa yang dapat mendukung jalannya proses belajar mengajar. Dengan modal penguasaan bahan, guru akan dapat menyampaikan materi perjalanan secara dinamis. Dalam hal ini yang dimaksud "menguasai bahan" bagi seorang guru, akan mengandung dua lingkup penguasaan materi, yakni:Menguasai bahan bidang studi dalam kurikulum sekolah dan menguasai bahan pengayaan atau penunjang bidang studi.

\section{Interaksi Siswa Dengan Objek Belajar}

Pola ineraksi guru dengann objek belajar di MIN Tolobali adalah sebagai organisator dalam pembelajaran. Guru telah mempersiapkan bahan pembelajaran bahkan jauh-jauh hari, berupa konsep pembelajaran . menyiapkan materi, media dan strategi belajar. Penguasaan bahan oleh guru seyogyanya mengarah pada spesifikatas ilmu kecakapan yang diajarkanya. Mengingat isi, sifat, dan luasnya ilmu, maka guru harus mampu menguraikan ilmu atau kecakapan dan apa-apa yang akan di ajarkanya kedalam bidang ilmu atau kecakapan yang bersangkutan. Penyusunan unsur-unsur atau informasi-informasi yang baik itu bukan saja untuk mempermudah peserta didik untuk mempelajarinya, melainkan juga memberikan gambaran yang jelas sebagai petunjuk dalam menetapkan metode pengajaran. Menguasai bahan sebelum guru itu tampil di depan kelas untuk mengelola interaksi belajar mengajar, terlebih dahulu harus sudah menguasai bahan apa yang dikontakkan dan sekaligus bahan-bahan apa yang dapat mendukung jalannya proses belajar mengajar. Dengan modal penguasaan bahan, guru akan dapat menyampaikan materi perjalanan secara dinamis. Dalam hal ini yang dimaksud "menguasai bahan" bagi seorang guru, akan mengandung dua lingkup penguasaan materi, yakni:Menguasai bahan bidang studi dalam kurikulum sekolah dan menguasai bahan pengayaan atau penunjang bidang studi.

\section{SIMPULAN}

Pola interaksi edukatif dalam proses pembelajaran di SDIT Insan Kamil dan di MIN Tolobali Kota Bima meliputi tiga pola yang digambarkan pada pola segitiga,yang mana pada setiap bagian tersebut mempunyai keterkaitan satu sama lain dengan bagian-bagian dalam pola tersebut terdapat guru, siswa dan objek belajar. Tiga pola interaksi edukatif tersebut adalah pola interaksi antara guru dengan siswa, guru dengan objek belajar serta siswa dengan objek belajar. dapat diketahui bahwa interaksi edukatif (hubungan timbal balik antara guru dengan 
peserta didik, guru dengan objek belajar serta peserta didik dengan objek belajar yang lain dalam proses kegiatan belajar mengajar) berlangsung baik di kelas maupun di luar kelas (di sekolah). Dalam hal ini tidak hanya guru saja yang aktif melainkan para peserta didik juga juga turut aktif dalam mengikuti proses belajar mengajar. Guru dalam mengajar tidak hanya sebatas pada "transfer of knowledge" tetapi juga "transfer of values", dengan demikian peserta didik tidak hanya mempunyai ilmu pengetahuan tetapi juga dapat mengamalkan ilmu yang dimilikinya dalam kehidupan sehari-hari, hal itu tercapai karena adanya proses pembiasaan dan keteadanan.

\section{DAFTAR PUSTAKA}

Sardiman. 2000. Interaksi dan Motivasi belajar mengajar. Jakarta: PT. Raja Grafindo Persada.

Sukmadinata, Nana Syaodih. 2007. MetodePenelitianTindakan. Bandung: Remaja Rosdakarya.

Muhajir, Noeng. 2003. MetodePenelitianKualitatif. Jogjakarta: Rake Sarasin.

Sukardi. 2009. Metodologi Penelitian Pendidikan, KompetisidanPraktinya. Jakarta: Bumi Aksara.

Rosyada, Dede. 2004. Paradigma Pendidikan Demokratis. Jakarta: Kencana.

Djamarah, Syaiful Bahri. 2000 Guru dan Anak Didik dalam Interaksi Edukatif. Jakarta: PT. RinekaCipta.

Ahmadi, Ruslan. 2005. Memahami Metodologi Penelitian Kualitatif, Malang: UIN Press.

Abdul Majid dan Dian Andayani. 2012. Pendidikan Karakter Perspektif Islam, Bandung: Remaja Rosdakarya.

Arief S. Sadirman. 1986. Media Pendidikan:Pengertian, Pengembangan, dan Pemanfatannya, Jakarta: Rajawali.

Ali Muhammad dan Asrori Muhammad. 2004. Psikologi Remaja, Jakarta: Bumi Aksara.

Azwar. 2004. Metodologi Penelitian, Yogyakarta: Pustaka Pelajar Ofifset.

Arikunto, Suharsimi. 2002. Prosedur Penelitian Suatu Pendekatan Praktik, Jakarta: PT. Rineka Cipa.

Arifin, Imron. 1988. Kepemimpinan Kepala Sekolah Dalam Mengelola Madrasah Ibtidaiyah dan Sekolah Dasar Berprestasi: studi multi kasus pada MIN Malang I, MI Mamba'ululum, dan SDN Ngaglik I Batu Malang, Malang: Disertasi UM tidak diterbitkan. 